\title{
Anuncios y próximos números
}

\section{PRÓXIMOS NÚMEROS}

\section{1 (2) 31 de mayo de 2018. Biograficidad y educación}

Coordinadores del monográfico: $\mathrm{M}^{\mathrm{a}}$ Eugenia Cardenal de la Nuez (Universidad de Las Palmas) y Francesc J. Hernàndez (Universitat de València).

El concepto de «biograficidad», desarrollado por Peter Alheit y Bettina Dausien, enfatiza la idea de que los individuos contemporáneos son empujados a ser reflexivos y a tomar la iniciativa para moldear sus propias vidas. El monográfico tiene como objetivo reunir contribuciones que exploren el problema de la relación entre los cursos de vida y los procesos formativos, abordando cuestiones como:

- La naturaleza y el sentido de las decisiones de educación y capacitación, tanto en general como en el contexto actual. Se puede prestar atención a la índole de las decisiones educativas o referirse a los planteamientos teóricos al respecto (desde la elección racional hasta el habitus).

- La relación entre las trayectorias educativas y el medio social. Aportaciones a la consideración de los «encauzamientos» de las biografías.

- Las biografías educativas de los grupos desposeídos. También su narración de los procesos formativos.

- Historias de vida y cualificación profesional.

- Biografía, educación y género. La construcción social de la biografía formativa de mujeres. También la relación entre biografía, formación y percepción del propio cuerpo.

- Biografías transnacionales y procesos formativos.

- Aprendizajes narrativos y metacompetencias narrativas relacionadas con la biografía.

- Así como los desafíos teóricos y metodológicos asociados a la investigación biográfica, con especial atención a las metodologías narrativas.

Este monográfico está abierto a textos en español, inglés o portugués. En el caso de artículos en español o en portugués, deberán acompañarse del título, resumen y palabras clave en inglés. En el caso de artículos en inglés, acompañarse del título, resumen y palabras clave en español. Por supuesto, si las/os autores desean enviar sus textos en los dos idiomas principales de este monográfico (español e inglés), serán bienvenidos y publicados en esos dos idiomas, siempre que las autoras/es se hagan cargo de sus respectivas traducciones. 
Los artículos podrán ser enviados a través de la plataforma de la Revista antes del 15 de marzo de 2018. Siguiendo las normas de edición de la Revista, todos los artículos serán evaluados por pares ciegos y seguirán el proceso de evaluación y selección/aceptación/rechazo ordinario de la Revista para su publicación definitiva.

Para enviar una propuesta, es necesario registrarse en la Revista (https://ojs.uv.es/rase). Para cualquier consulta pueden dirigirse a María Eugenia Cardenal (mariaeugenia.cardenal@ulpgc.es) o Francesc J. Hernàndez (francesc.j.hernandez@uv.es).

\section{1 (2) May, 31 ${ }^{\text {st }}$ 2018. Biograficity and Education}

Special Issue Coordinators: $\mathrm{M}^{a}$ Eugenia Cardenal de la Nuez (Universidad de Las Palmas) y Francesc J. Hernàndez (Universitat de València).

The concept of «biograficity», developed by Peter Alheit and Bettina Dausien, emphasizes the idea that contemporary individuals are pushed to be reflexive and to take the initiative to shape their own lives. The objective of the monograph is to gather contributions that explore the problem of the relationship between life courses and training processes, addressing issues such as:

- The nature and meaning of education and training decisions, both in general and in the current context. You can pay attention to the nature of the educational decisions or refer to the theoretical approaches in this regard (from the rational choice to the habitus).

- The relationship between educational trajectories and the social environment. Contributions to the consideration of the «channeling» of the biographies.

- The educational biographies of the dispossessed groups. Also his narration of the formative processes.

- Life stories and professional qualification.

- Biography, education and gender. The social construction of the formative biography of women. Also the relationship between biography, training and perception of one's own body.

- Transnational biographies and training processes.

- Narrative learning and narrative metacompetences related to biography.

- As well as the theoretical and methodological challenges associated with biographical research, with special attention to narrative methodologies.

This monographic is open to texts in Spanish, English or Portuguese. In the case of articles in Spanish or Portuguese, they must be accompanied by the title, abstract and key words in English. In the case of articles in English, accompany the title, summary and keywords in English. Of course, if the authors wish to send their texts in the two main languages of this journal (Spanish and English), they will be welcome and published in those two languages, provided that the authors take charge of their respective translations. Following the publication guidelines of this journal, all articles will be evaluated using the journal's blind review and following the regular process of evaluation and selection/acceptation/rejection for their definitive publication.

To send a proposal please register in the journal's website (https://ojs.uv.es/rase). All proposals will be sent though the journal's platform before March 15 ${ }^{\text {th }}, 2018$.

For any questions, please contact María Eugenia Cardenal (mariaeugenia.cardenal@ulpgc.es) or Francesc J. Hernàndez (francesc.j.hernandez@uv.es). 


\section{1 (3) 30 de septiembre de 2018. Educación y medios de comunicación}

Coordinadores del monográfico: Sergio Andrés Cabello, Universidad de La Rioja (España) y Margarita Machado-Casas, University of Texas at San Antonio (Estados Unidos).

La educación es una de las cuestiones que cuentan con mayor presencia en los medios de comunicación. El debate alrededor de la misma es continuo y abarca desde su importancia y significado, especialmente en un mundo cada vez más complejo y en constante transformación, a la valoración y comparación de los resultados de los estudiantes a través de informes como PISA y TALIS, entre otros, generándose rankings que alimentan dicho debate. Además, los medios de comunicación se hacen eco y difunden numerosos estudios e informes en relación a todos los aspectos vinculados a la educación, desde su papel en relación a las desigualdades al peso de las inversiones públicas, sin olvidar a cada uno de los agentes presentes en el sistema educativo. Igualmente, es un debate que abarca todos los niveles, desde la primera etapa de la Educación Infantil hasta la postuniversitaria. Y, por otra parte, numerosos medios de comunicación generalistas han incorporado secciones o subsecciones dedicadas a la educación, con periodistas especializados en la cuestión, que han dado lugar al surgimiento de publicaciones sobre el tema, además de dar voz a especialistas en este ámbito tanto a través de la recogida de noticias e investigaciones como mediante artículos de opinión.

El presente monográfico de la Revista Sociología de la Educación (RASE) abarca la evolución, la presencia, la importancia y el tratamiento que los medios de comunicación dan a la educación. Las contribuciones presentadas podrán tener en consideración diferentes cuestiones como las siguientes:

- Desde una perspectiva más general, el valor otorgado por los medios de comunicación a la educación, así como el tratamiento que hacen de la misma.

- Cómo tratan los medios de comunicación la educación, si lo hacen de forma objetiva o no, si su conocimiento de la misma es adecuado o tratan las cuestiones de forma superficial, si muestran una imagen real de lo que ocurre en la educación o una parcial que reproduce estereotipos y perjuicios, etc.

- Analizar qué aspectos específicos de la educación son los que cuentan con mayor presencia en los medios de comunicación, pudiéndose centrar las contribuciones un uno de ellos.

- Las transformaciones del valor de la educación a través de los propios medios de comunicación y cómo se están reflejando en los mismos teniendo en consideración los procesos de transformación de la educación en un valor de mercado.

- La existencia o no de una ideología subyacente en los medios de comunicación en relación a la educación y a su valor y cómo se construyen determinados relatos sobre la misma.

- La generación de debates en relación a la educación y cómo se produce una retroalimentación entre los diferentes agentes implicados.

- La transformación de la formación postobligatoria, especialmente la universitaria, y su presencia en los medios de comunicación, con la incorporación de nuevas cuestiones como el emprendimiento por ejemplo, y las ideologías subyacentes en este proceso.

- Cómo reflejan los medios de comunicación la situación de los diferentes agentes educativos, en todos sus niveles y etapas, pudiendo centrarse en un colectivo específico y sus problemáticas. 
- La visibilidad del debate sobre la educación en los medios de comunicación a través de las Redes Sociales y su valor para la difusión y concienciación sobre las cuestiones tratadas.

Este monográfico está abierto a textos en español e inglés. Los resúmenes y las palabras claves serán presentados en ambos idiomas. si bien, el cuerpo del artículo puede ser escrito únicamente en uno de estos tres idiomas. Por supuesto, si las/os autores desean enviar sus textos en los dos idiomas de este monográfico, serán bienvenidos y publicados en esos dos idiomas, siempre que las autoras/es se hagan cargo de sus respectivas traducciones. Siguiendo las normas de edición de la Revista, todos los artículos serán evaluados por pares ciegos y seguirán el proceso de evaluación y selección/aceptación/rechazo ordinario de la Revista para su publicación definitiva.

Para enviar una propuesta, es necesario registrarse en la Revista (https:/ /ojs.uv.es/rase). Todas las propuestas serán enviadas a través de la plataforma de la Revista antes del 28 de febrero de 2018, en forma de un breve resumen de 600 palabras como máximo, en español o inglés. Los resúmenes serán evaluados por un comité de evaluación y la resolución devuelta a los autores y autoras el 15 de marzo de 2018 como muy tarde. Todas las propuestas completas serán enviadas hasta el 15 de junio de 2018 (incluido).

\section{1(3) September, $30^{\text {th }}$ 2018. Education and Media.}

Special Issue Coordinators: Sergio Andres Cabello, Universidad de la Rioja (Spain) and Margarita Machado-Casas, University of Texas at San Antonio (United States).

Education is one of the topics with the most presence in the media. The debate surrounding it is continuous and goes from the importance of education and meaning, especially in an ever complex and ever transforming world, to the assessment and comparison of the students' scores using reports like PISA and TALIS, among others, generating rankings that further fuel said debate. Also, the media outlets take this information and spread the many studies and reports that had to do with every aspect of education, from its role in the relationship between inequalities to the weight public investment has not forgetting every single one of the involved agents in the education system. Equally, this is a debate that covers all levels, from the first levels of elementary education to post-graduate education. And, what's more. Many generalist media have incorporated sections or subsections dedicated to education, with specialized journalists. This has allowed the rise of publication specialized in education, as well as allowed to give voice to the specialists in this field, using both the recompilation of news and research as well as opinion articles.

- The present monographic from the Revista Sociología de la Educación (RASE), involves the evolution, presence, importance, and treatment that media affords to education. The presented contributions would discuss different subjects on the matter as follows:

- From a more general perspective, the value given to education from the media outlets, as well as the treatment they give to it.

- How media address and treats education, if the media is objective or not, if their knowledge of education is adequate or they approach the subjects from a superficial standpoint. If the media shows a real portrait of what is happening in education or a partial viewpoint that only helps perpetuate stereotypes and prejudices, etc.

- Analyze what specific aspects of education are the ones that have the biggest presence in the media, allowing for focusing in the specific contributions from one of them. 
- The changes and transformation of the value of education through the own media and how they are reflecting themselves having into consideration the processes of transformation of education in a market value.

- The existence or not of an underlying ideology in the media relating to education and its value as well as how portraits about education are constructed.

- The generation of debate in relationship to education and how feedback is produced among the different agents involved.

- The transformation of the post-mandatory education, especially at the college level, and its presence in the media. With the incorporation of new subjects like entrepreneurship for example, and the subjacent ideologies regarding this matter.

- How the media portraits the situation of the different educative agents in all the levels and stages instead of focusing on a specific collective and its quandaries.

- The debate's visibility about education and the media in the social networks as well as its value in the spread and awareness about the educational matters discussed.

This monographic is open to texts in Spanish and English. The summaries and key words will be presented in both languages. However, the body of the article could be written in only one of the before mentioned languages. Of course, if any of the authors wishes to send in both languages, they will be welcomed and published in these two languages as long as the authors provide their translations. Following the publication guidelines of this journal, all articles will be evaluated using the journal's blind review and following the regular process of evaluation and selection/acceptation/rejection for their definitive publication.

To send a proposal please register in the journal's website (https://ojs.uv.es/rase). All proposals will be sent though the journal's platform before February $28^{\text {th }}$, 2018. Proposals should be no more than 600 words, in Spanish or English (or both). The abstracts will be evaluated by the journal's evaluation committee and decisions will be emailed to authors on March 15 ${ }^{\text {th }}, 2018$ at the latest. All completed proposals will be send until June $15^{\text {th }}, 2018$. 